\title{
Identity, Technology and their Confluence: Governmentality in the Digital Age
}

\author{
Chris Dent \\ Murdoch University, Australia
}

\begin{abstract}
The digital age has posed significant challenges for the governance of society. These challenges stem, in part, from the fact that many of the practices of governance arose in the pre-digital world. Foucault's notion of 'governmentality' is a framework that can take account of the different sets of practices of governance. Comparing current practices with those highlighted by Miller and Rose's 'three families' of governmentality suggests that twenty-first century governance operates as a new, fourth family. This research demonstrates this through an examination of aspects of the law-such as welfare and libel law - that have changed since the nineteenth century, with those changes mapping to the different families. In other words, the manner in which we, as legal subjects, have been constituted has changed, and will continue to change. As such, while specific practices such as fake news are seen to be problematic now, any reactions to them are historically contingent-and so the practices may not be seen to be an issue in a couple of decades time.
\end{abstract}

Keywords: Foucault; governmentality; fourth family; digital self; fake news.

\section{Introduction}

We are now in a century in which the digital world, and its attendant algorithms, play a significant role in the governance of society. They have been around long enough for the practices associated with them to have become integral to certain aspects of our selves. This article adopts a broadly Foucauldian framework to explore this issue. Michel Foucault applied the term 'governmentality' to the practices of governance evident in the West over the past couple of centuries. ${ }^{1}$ Other writers have developed his ideas, and have described three 'families' of governmentality that have been evident up until the end of the twentieth century. ${ }^{2}$ The argument here is that the nature of governance has changed even further over the past decade or two. That is, the practices, including those from the law, that constitute individuals and corporations have adapted and responded to shifts in those aspects of societal regulation inherent in the digital sphere.

The analysis here focuses on a restricted number of nation-states, namely the United Kingdom (UK) and Australia; ${ }^{3}$ as such, it is less applicable to countries with different governance structures. Expressed differently, the past has provided a set of conditions of possibility ${ }^{4}$ that describe how we have got to where we are today, and those conditions are tied to specific jurisdictions. The changes identified here are not, overall, guided by conscious decisions - they are the sum of the everyday actions of those who operate from a range of discursive positions. As such, any redirection is beyond the power of any individual or entity of governance. Further, any digital challenge such as fake news should not be seen as a unique, solvable, problem; instead, it is an embedded part of twenty-first century governance. The only upside is that problematic practices evident now will, in turn, be yesterday's news (at some point).

\footnotetext{
${ }^{1}$ See, for example, his chapter, "Governmentality."

${ }^{2}$ Miller, Governing the Present, 17-18.

${ }^{3}$ The discussion of specific historical laws, here, will refer to those of the UK. The more recent law will be a combination of UK and Australian law, to show that the discussion has wider applicability.

${ }^{4}$ The phrase "conditions of possibility" is, specifically, used to reduce inferences of causation between fake news and the past: Hunt, Foucault and Law, 6-7. The phrase's use is indicative of a broadly Foucauldian genealogical method being adopted; see, further, Foucault, "Questions of Method."
} 


\section{Background}

To make the argument, there needs to be a more complete description of its base theory. As such, this section will provide more detail of Foucault's understanding of governmentality. To round it out, there will be an engagement with the role of 'law' in this analysis, given that it has had, at times, been seen to have a minimal role in Foucault's scheme.

\section{Overview of Governmentality}

Foucault described 'governmentality' in terms of 'techniques and procedures for directing human behaviour ... [that could be the] government of children, government of souls and consciences, government of a household, of a state, or of oneself'. ${ }^{5}$ Governmentality can be understood as both the (self-)governance of individuals (the 'conduct of conduct' ${ }^{\prime}$ ) and the multiple government rationalities that are engaged to govern the population. ${ }^{7}$ Three aspects of the theory need to be highlighted. First, governmentality exists as an 'ensemble formed by the institutions, procedures, analyses and reflections, the calculations and tactics ... a whole series of specific governmental apparatuses, and ... a whole complex of savoirs' ${ }^{8}$ Therefore, governmentalist practices are diffuse throughout society, without there being a single organ of governance. A 'population', as the 'target' of the 'ensemble', ' can be the entire body of citizens of a given nation, or a smaller body of people, such as the members of a particular educational discourse or profession. The central point of this use of the term 'population' is that there is a separable body of subjects that is constructed and transformed by the institutions and practices of a particular discourse. This separable body of subjects is 'knowable' and can be the target of inquiry and, more importantly, the target of specific practices of government rationalities.

Central to the relationship between the members of a population and governmentalist practices is the process of subjectification - the 'way a human being turns him- or herself into a subject' ${ }^{10}{ }^{1}$ Foucault's assertion that the 'juridical mode of governance ... is increasingly replaced by ... a power that exerts a more positive influence on life, undertaking to administer it, multiply it, and impose upon it a system of regulations and precise inspection' ${ }^{11}$ is based on the more active, yet largely unrecognised, role that individuals play in their creation as subjects. Individuals are a necessary part of the process that gives them 'the rules of law, the techniques of management, and ... the practices of self'. ${ }^{12}$

At the heart of the processes of subjectification is the contention that 'the self is not given to us' ${ }^{13}$ However,

it is not enough to say that the subject is constituted in a symbolic system. It is not just in the play of symbols that the subject is constituted. It is constituted in real practices—-historically analysable practices. ${ }^{14}$

These practices are not to be understood as commands from a higher authority. Instead they can be understood to operate as accepted and internalised patterns of action. For Foucault, no individual exists prior to discursive inscription, for 'discursive formations produce the object about which they speak'. ${ }^{15}$ This is done through webs of power relations ${ }^{16}$ - through the multiplicity of interpersonal relationships that exist in the rearing of children and adults. From this perspective, the mechanisms of discursive control 'homogenise populations through knowledge, separation, observation, and experiment, but do so only by "individualising" people in cells and classroom desks, by examination and experimentation' ${ }^{17}$ Therefore, these internalised practices produce an 'individual' complicit in her or his own constitution as a subject; we are governed through the 'regulated freedom ${ }^{18}$ of apparent choice, ${ }^{19}$ through our own roles in the conducting of our own conduct. ${ }^{20}$

\footnotetext{
${ }^{5}$ Foucault, "On the Government of the Living," 81.

${ }^{6}$ Foucault, "Subject and Power," 341.

${ }^{7}$ For Foucault, the "state is nothing more than the mobile effect of a regime of multiple governmentalities": "Birth of Biopolitics," 77.

${ }^{8}$ Foucault, Archaeology of Knowledge, 15 n2. "Savoir", in this sense, means a body of knowledge, its rules of formation and the conditions necessary for the knowledge to be enunciated.

${ }^{9}$ Foucault, "Governmentality," 102.

${ }^{10}$ Foucault, "Afterword-the Subject and Power," 208.

${ }^{11}$ Ewald, "Norms, Discipline, and the Law," 138.

${ }^{12}$ Foucault, "Ethics of the Concern for Self," 18.

${ }^{13}$ Foucault, "On the Genealogy of Ethics," 237.

${ }^{14}$ Foucault, "On the Genealogy of Ethics," 250.

${ }^{15}$ Cited in Dreyfus, Michael Foucault, 61.

${ }^{16}$ Foucault, "Two Lectures," 98.

17 Bové, "End of Humanism," 29.

${ }^{18}$ Barron, "Foucault and Law," 976.

${ }^{19}$ No matter how shallow that freedom is: Rose, Powers of Freedom, 97.

20 "Individuals are constituted as active participants in the network of relations that form them": Barron, "Foucault and Law," 975.
} 


\section{Role of Law in Governmentality}

The fact that the theory acknowledges that a range of practices and procedures influences the actions of individuals suggests that the law does not fully control the behaviour of individuals. ${ }^{21}$ For Foucault himself, the 'law is not what is important'. ${ }^{22}$ Expressed differently, law is 'increasingly incorporated into a continuum of apparatuses (medical, administrative and so on) whose functions are for the most part regulatory'. ${ }^{23}$ Either characterisation sees our behaviour constrained by norms and practices, rather than the extant law.

With respect to the regulation of identity, for example, there are legal requirements around birth registration ${ }^{24}$ and claiming citizenship of a specific nation ${ }^{25}$ however, most other aspects of their identity are developed, and maintained, with minimal influence from the law. The familial relationships that they maintain may be separate to the relationships specified in law. ${ }^{26}$ Identity is also created and reinforced through choices of self-expression, including attire and other social relations. Save for the provisions around indecent exposure ${ }^{27}$ and consorting laws ${ }^{28}$ in some jurisdictions, the law is silent as to these aspects of identity; therefore, they are better understood to be controlled through the internalisation and expression of norms ${ }^{29}$ From this perspective, then, expressions of identity are aspects of self-governance; however, specific laws have very little influence on the day-to-day exercises of self-identity that all members of the population practice.

Conversely, it could be suggested that corporations, as creatures of legislation, are more constrained by the law. There are, for example, specific statutory obligations that befall their directors (and other officers) ${ }^{30}$ one of which is that they should 'exercise their powers and discharge their duties in good faith in the best interests of the corporation'.$^{31}$ These interests may be understood as 'maximising the company's profits for distribution among the shareholders' ${ }^{32}$ The decisions of corporations are still the decisions of office holders or employees, and they, as individuals, are swayed by a specific set of practices of governance, including the practices that contribute towards their personal wealth maximisation. It should not be forgotten that the corporation's legislation itself was written, and passed, by those who have been constituted, in part, as homo economicus. ${ }^{33}$ Unsurprisingly, those who are constituted to pursue profit are behind the laws that require corporations to do the same.

In addition, the common law is the product of individual actions. Two examples of this are, first, Lord Atkin's choice of 'neighbour' in the 'neighbour principle' of Donoghue v Stevenson ([1932] AC 562), which is said to have a conscious 'religious basis' ${ }^{34}$ Second, Lord Eldon's conservatism is said to have contributed to expanded use of 'duty' in the common law. ${ }^{35}$ In other words, it is not only those who are seen to be 'governed' by law who are constituted by practices of governance but also those who occupy positions of governance.

A further example of rules by practices, instead of laws, arises from cross-border commercial activities. In most cases, the law of one jurisdiction will not have significant effect on the behaviour of a corporation (or individual) domiciled in another jurisdiction save, of course, for infringements that took place in the first country's territory. That said, the potential for punitive

\footnotetext{
${ }^{21}$ One theorist goes so far as to call individuals "ungovernable": Black, "Critical Reflections on Regulation," 6-7.

${ }^{22}$ As quoted in Hunt, "Foucault's Expulsion of Law," 7.

${ }^{23}$ Foucault, History of Sexuality, 144.

${ }^{24}$ For example, Births, Deaths and Marriages Registration Act 1998 (WA).

${ }^{25}$ For example, Australian Citizenship Act 2007 (Cth).

${ }^{26}$ For example, "lineal relatives" for the purposes of certain sexual offences under the Criminal Code 1913 (WA) s. 328; or the determination of relationships under the Wills Act 1970 (WA) s. 31.

${ }^{27}$ For example, a "person shall not, in or within view from a public place or a school, willfully and obscenely expose his or her person": Summary Offences Act 1988 (NSW) s. 5.

${ }^{28}$ For example, the potential limitations on individuals under a supervision order: Crimes (High Risk Offenders) Act 2006 (NSW) s. $11(1)(\mathrm{g})$; the "anti-bikie" provisions reflected in the "control orders" that prevent those under such orders associating with each other: Crimes (Criminal Organisations Control) Act 2012 (NSW) s. 26; and the more general, "consorting" offence under Crimes Act 1900 (NSW) s. 93X.

${ }^{29}$ To be clear, in this context, norms are standards of conduct that are "the common measure" of behaviour and the "modern form of the social bond" (Ewald, "Justice, Equality, Judgment," 108).

${ }^{30}$ Corporations Act 2001 (Cth) Part 2D.1.

${ }^{31}$ Corporations Act 2001 (Cth) s. 181(1).

${ }^{32}$ McConvill, "Interaction of Directors' Duties and Sustainable Development," 131.

${ }^{33}$ For Foucault, to be constituted as homo economicus is to be constituted as an "entrepreneur ... being for himself his own capital, being for himself his own producer, being for himself the source of his earnings": "Birth of Biopolitics", 226. "Economic Man", then, is constituted as being responsible for "his" own financial well-being and as being endowed with the capacity to fulfil that responsibility; "he" is constituted as being self-regulating with respect to his own income, his own debts and his own economic future.

${ }^{34}$ Leiboff, Legal Theories, 103.

${ }^{35}$ Dent, "Introduction of Duty into English Law."
} 
action could guide the behaviour of a non-resident entity. A corporation could, for example, standardise their operation across all the countries in which they operate so that their actions would not be against the laws of the most restrictive of jurisdictions. ${ }^{36}$ In that case, the laws of the restrictive country could be seen to be adopted as a norm by the corporation, despite it not being legally required in the more liberal jurisdiction. In that instance, the law of the country in question is not a simple, immutable requirement, but a changeable practice of governance.

\title{
Three 'Families' of Governmentality
}

The next aspect of this analysis is an engagement with Miller and Rose's articulation of the three 'families' of governmentality. To be clear, these families are 'not temporal epochs succeeding one another, but resemblances in ways of thinking and acting' ${ }^{37}$ As such, certain practices remain constant from one period to another, while others change - therefore, there is no hard and fast limit to any of them. Each of the three families will be discussed in turn, in preparation for consideration of us now being in the fourth.

\section{First Family—Nineteenth Century}

The first family is that of 'classical liberalism' of the nineteenth century. In that period,

\begin{abstract}
the state limited itself by designating zones exterior to it — private life, the market, civil society ... [And] the political apparatus depended on the activities of multiple governing agents external to it - the churches, philanthropic organizations, trade unions and friendly societies. ${ }^{38}$
\end{abstract}

Notably, from a legal history perspective, it was the pinnacle of the 'laissez-faire' approach to commercial relations. ${ }^{39}$ In terms of welfare relief, specifically, there was the series of statutes regulating friendly societies, with the first being the Friendly Societies Act $1875 .{ }^{40}$ There was also the establishment of the Poor Law Commission. ${ }^{41}$ Two aspects of this reform are worth highlighting. First, the funding for the workhouses was still drawn from the community, rather than the central government, and second, it was still administered at the parish level, so the church organisation remained the focus of the institutionalised control of the poor.

There were a range of legal changes that can be linked with the conditions of possibility of the 'fake news' problematisation. ${ }^{42}$ The first is that the Births and Deaths Registration Act 1836 was an early attempt to 'know' the population. ${ }^{43}$ This can be linked with the developing of field of classical economics, ${ }^{44}$ as can the Poor Law Commission. The economy itself underwent change through the passing of both the Joint Stock Companies Act 1844 and the Limited Liability Act 1855, giving rise to the 'limited liability' company. ${ }^{45}$ The education sector developed, being central to the control of knowledge generally, over the

\footnotetext{
${ }^{36}$ See, for example, the discussion in Lavenex, "EU Rules beyond EU Borders."

${ }^{37}$ Miller, Governing the Present, 17.

${ }^{38}$ Miller, Governing the Present, 17.

${ }^{39}$ That is, "contracts when entered into freely and voluntarily shall be held sacred and shall be enforced": Printing and Numerical Registering Company v Sampson (1875) LR 19 Eq 462, 465.

${ }^{40}$ A friendly society could include, inter alia, the following purposes: "For the relief or maintenance of the members, their husbands, wives, children, fathers, mothers, brothers or sisters, nephews or nieces, or wards being orphans, during sickness or other infirmity, whether bodily or mental, in old age (which shall mean any age after fifty,) ... [and] For the relief or maintenance of the members when on travel in search of employment, or when in distressed circumstances, or in case of shipwreck, or loss or damage of or to boats or nets": s. 8(1).

${ }^{41}$ Under the Poor Law Amendment Act 1834. The Poor Law Commission was replaced with the Poor Law Board in 1847; however, the system it oversaw did not change significantly.

${ }^{42}$ Foucault is quoted as saying that "problematisation" is the "ensemble of discursive and non-discursive practices that make something enter into the play of true and false and constitute it as an object of thought (whether in the form of moral reflection, scientific knowledge, political analysis etc)": Rabinow, 12-13. That is, there is no "natural" problem that requires the attention of the governing (or for analysis) - particular issues "become" problems that need to be the subject of action.

${ }^{43}$ The first decennial census in the UK was carried out in 1801; however, until 1841, the census was only an "account of the number of persons" in the jurisdiction: Census Act 1800 s. 3.

${ }^{44}$ For a discussion of the Poor Law reforms in light of the work of Robert Malthus, see Vinokur, "Malthusian Ideology." For a discussion of the Poor Laws and population numbers, see Huzel, "Demographic Impact of the Old Poor Law." In terms of the argument in the present article, Vinokur noted that, prior to the reforms, the "poor rates were administered in a decentralised fashion, in each parish, by the Justices of the Peace. They were the King's servants, but not in his pay nor in his dependence, they were country landlords who combined judicial, political, economic and administrative power": at 174.

${ }^{45}$ The Limited Liability Act 1855 only provided limited liability to companies fully registered under the Joint Stock Companies Act 1844 (s.2). For a discussion of limited liability in the nineteenth century, see Lobban, "Corporate Identity and Limited Liability."
} 
course of the nineteenth century ${ }^{46}$ and the Public Libraries Act 1850 was passed that made knowledge more freely available within the population. With respect to the news media, there was the 'yellow press' of the 1890s; preceding that, there were the 'lurid' Sunday papers of the 1850s and the rise of the Daily Telegraph after the abolition of the stamp tax in $1855 .{ }^{47}$ The spread of knowledge in England was transformed through not only mechanisation of the presses, but also through the development of telegraphy. This was understood to affect the governance of territory as was recognised, ${ }^{48}$ at the time, by the House of Lords:

Telegraphs, postal systems, railways, steam, have brought all parts of the world into touch. Communication has become easy, rapid and cheap. Commerce has grown with our growth, and trade is ever finding new outlets and methods that cannot be circumscribed by areas or narrowed by the municipal laws of any country. ${ }^{49}$

A range of technology, then, was generated by knowledge, ${ }^{50}$ and it was used to disseminate knowledge (either person-to-person or via the news media).

The final point to be made relates to an area of domestic law that connects 'truth', individuals and the press - that of libel. ${ }^{51}$ That area of law became more organised over the nineteenth century, including the development of classifications of defences. ${ }^{52}$ It was also the time when a duty component was added to the defence of 'qualified privilege', in which a defamatory statement could be made if its recipient and an interest in the knowledge. More fully:

In general, an action lies for the malicious publication of statements which are false in fact, and injurious to the character of another, and the law considers such publication as malicious, unless it is fairly made by a person in the discharge of some public or private duty, whether legal or moral, or in the conduct of his own affairs, in matters where his interest is concerned. ${ }^{53}$

As such, the law developed in such a way as to authorise individuals to make statements that would otherwise be sanctionable to further the public good,${ }^{54}$ in keeping with the basis of the first family of governmentality.

\section{Second Family-Early Twentieth Century}

The second family is described by Miller and Rose in terms of 'governing from the social point of view' ${ }^{55}$ More fully, government sought to,

combat the twin threats of unbridled market individualism and communist revolution. This was the original third or middle way to save private enterprise, to transform subjects into social citizens with social rights ... It entailed a new conception of the state as the ultimate guarantor of the welfare of the individual. ${ }^{56}$

\footnotetext{
${ }^{46}$ It was in 1870 that "universal compulsory education" came to England: Russell, Freedom and Organisation, 135.

${ }^{47}$ Seaman, Victorian England, 420-421. There were, of course, more conservative publications. Conboy noted that there was a "broadly educational aspect" to many of the mid-century newspapers: Press and Popular Culture, 84.

${ }^{48}$ Another aspect of the governance of territories evident in the nineteenth century was the greater use of treaties, including multilateral treaties, such as the 1865 International Telegraph Union. Reuter noted that the "idea that a treaty which is binding upon different States by the same terms constitutes a single legal instrument first appeared at the [1815] Congress of Vienna": Introduction to the Law of Treaties, 4. From one perspective, multilateral treaties can be seen as the beginning of the end of the Westphalian nation-state, although they have continued to function, to an extent, despite the limitations to their self-governance. These meant that each State agreed to limit their own intra-jurisdictional power for the benefits that arose from the agreements.

${ }^{49}$ Nordenfelt $v$ Maxim-Nordenfelt [1894] AC 535, 556.

${ }^{50}$ MacLeod noted, when discussing the development of the steam engine, that the "more complex the machinery, the more it was dependent on the knowledge derived from centuries of experience": Heroes of Invention, 165.

${ }^{51}$ Libel law can be seen as the legal regulation of interpersonal truth - with truth having been central to that area of law since its institution in England in the thirteenth century: see Dent, "Locus of Defamation Law."

52 See, for example, Dent, "Privileged Few." The law more generally became more interested in organising knowledge. An instance of this was the growing use of registers - a "technology" for organising knowledge that has legal effect. One of the first centralised State registers was the above-mentioned Register of Births, Deaths and Marriages. The registers under the Joint Stock Companies Act 1844, have also been alluded to. Others include the Registers of Medical Practitioners (under the Medical Act 1858), pharmacists (Pharmacy Act 1852), friendly societies (Friendly Societies Act 1875), ships (Merchant Shipping Act 1854) and even deserters from merchant ships (Merchant Shipping Act 1894).

${ }^{53}$ Toogood v Spyring (1834) 1 C M \& R 181, 193.

${ }^{54}$ Libel law also facilitated the governance of England through the development of the "fair report" form of qualified privilege. For example: "A fair account of what takes place in a Court of justice is privileged ... It is of great consequence that the public should know what takes place in Court ... The inconvenience therefore arising from the chance of injury to private character is infinitesimally small as compared to the convenience of publicity": Davison v Duncan (1857) 7 El \& B1 229, 231.

${ }^{55}$ Miller, Governing the Present, 17.

${ }^{56}$ Miller, Governing the Present, 17-18.
} 
To continue the example of welfare provision, ${ }^{57}$ in 1919, the Ministry of Health took over the responsibilities of the Local Government Board (which had taken over the role of the Poor Law Board) ${ }^{58}$ Further, the National Insurance Act 1911 provided for workers, their employers and the government to contribute to an insurance scheme. The benefits of the scheme were to cover, inter alia, 'medical treatment and attendance, including the provision of proper and sufficient medicines ... Treatment in sanatoria or other institutions ... [and] Periodical payments whilst rendered incapable of work by some specific disease or by bodily or mental disablement'. ${ }^{59}$ These changes can be seen to reflect an increased role for the national government and, therefore, an increased level of importance in the health and welfare of the members of society.

With respect to issues of concern for this article, in the first half of the twentieth century, the relationship between the individuals and the State changed with the expansion of suffrage to remove the property requirement to voting and to include women. ${ }^{60}$ As a form of control, and increasingly one of identification, drivers' licences were introduced under the Motor Car Act 1903. The requirement to prove a degree of knowledge and skill was instituted under the Road Traffic Act $1934 .{ }^{61}$ Therefore, the nineteenth-century knowledge requirements for certain professions ${ }^{62}$ can be seen to have expanded to cover the wider population in an instance in which their actions put others at risk.

Knowledge, more generally, began to be deployed in governance itself; according to Miller and Rose, the second family of governmentality 'depended heavily on the invention of new professionals of the social'. ${ }^{63}$ Knowledge as a subject of investigation itself developed, including Karl Popper's focus on falsifiability as the distinction between science and nonscience. ${ }^{64}$ In terms of economic theory, neoclassical economics came to dominate the public discourse. ${ }^{65}$ The discipline differentiates between macro and microeconomics, with the latter privileging the role of the 'rational' individual. ${ }^{66}$

Two aspects of mass communication may be highlighted to round out this discussion. First, the technology was commercialised with respect to broadcast media. The British Broadcasting Corporation was granted its Royal Charter in the 1920s and began to provide radio programmes to the British public, with broadcasting considered a 'public service' ${ }^{67}$ In the 1930 s, the British Broadcasting Corporation began its television service. ${ }^{68}$ Here, then, the State assumed control over the initial wireless broadcasts. Second, in the law of libel, the House of Lords decision E. Hulton v Jones ${ }^{69}$ clarified two points. ${ }^{70}$ The first of these was that distributors were liable 'irrespective of fault on authors of defamatory material'. ${ }^{71}$ This meant that distributors, often being corporations, could be used to limit such publications, without chasing all authors. The second point is that the 'presumption of malice was irrebuttable'; ${ }^{72}$ this, too, simplified the control of socially undesirable statements by removing the need for the courts to investigate the individual motivations of every libel defendant.

\section{Third Family_Late Twentieth Century}

The third family of governmentality, the 'advanced liberalism' form, 'entailed the deployment of new technologies of governing from a centre through powerful means of governing at a distance', including the deployment of 'audits, budget, standards, risk

\footnotetext{
57 "Welfare" is central to the governmentalist approach: Hunt, Foucault and Law, 54.

${ }^{58}$ Ministry of Health Act 1919.

${ }^{59}$ Section 8.

${ }^{60}$ Representation of the People (Equal Franchise) Act 1928.

${ }^{61}$ Section 6.

${ }^{62}$ For example, under the Medical Act 1858 and the Pharmacy Act 1852.

${ }^{63}$ Miller, Governing the Present, 18.

${ }^{64}$ Popper, Logic of Scientific Discovery, translated from Logik der Forschung (1934).

${ }^{65}$ Further, the study of macroeconomics focused on trade policy. It was in this period that the General Agreement on Tariffs and Trade was signed, linking economic policy with decisions to restrict the options available to governments when seeking to adjust their economy. And, of course, it was in the first half of the twentieth century that the League of Nations was created, and then the United Nations with its Universal Declaration of Human Rights.

${ }^{66}$ The standard model attributes certain characteristics to that individual, including that they are rational, are motivated by utility maximisation, are Bayesian probability operators, have consistent time preferences according to the discounted utility model and their utility is governed by purely selfish concerns: Wilkinson, Introduction to Behavioural Economics, 5 .

${ }^{67}$ Briggs, History of Broadcasting, vol. 1, 229.

${ }^{68}$ See, generally, Briggs, History of Broadcasting, vol. 2.

${ }^{69}$ E. Hulton $v$ Jones [1910] AC 20.

${ }^{70}$ It may be further noted that it was only in 1898 that the "House of Lords was bound by its past decisions": Cross, Precedent in English Law, 102, citing London Tramways v London County Council. As such, any statements of law from the Court, in the first half the twentieth century, had more importance than its statements from the nineteenth century.

${ }^{71}$ Mitchell, Making of the Modern Law, 133.

${ }^{72}$ Mitchell, Making of the Modern Law, 187.
} 
management, targets, shadow of the law etc' ${ }^{73}$ In terms of welfare, the system was reformed by the National Assistance Act 1948, which applied to those who did not make contributions under the National Insurance Act 1911. Therefore, it gave the State sole responsibility for their welfare. By the 1990s, the emphasis of State policy had changed, and under the Social Security Contributions and Benefits Act 1992, there was the stipulation that a person would be disqualified from receiving a benefit when they 'without good cause neglected to avail [themselves] of a reasonable opportunity of employment' ${ }^{74}$ This was not in the 1948 statute and conceives of the recipient as being more active in the process, and required them to potentially sacrifice their preferences for a career to limit their recourse to State funds.

In terms of the constitution of individual subjects, the rise in consumerism enabled the greater self-expression and selfidentification of individuals; to use Miller and Rose's words, this period saw the shift 'from mass consumption to individualised and diversified consumption regimes'. ${ }^{75}$ The second half of the twentieth century also saw the capacity for individuals to take on the power of states through the use of investor-state dispute settlement proceedings. ${ }^{76}$ With respect to knowledge, there was a greater interplay between disciplines, such as the law and economics movement, and a challenging of the authority of such disciplines. ${ }^{77}$ As such, the monopolisation of 'Truth' by specific bodies of knowledge was subject to significant challenge.

The interaction between individuals, society and the State also changed in this period. There was, for example, a rise in mass protests that expressed political opinion - as opposed to the assertion of political identity ${ }^{78}$ or attempts at revolution-such as the anti-nuclear peace and the poll tax protests. ${ }^{79}$ This can be seen to be reflected in the defamation law of the time:

Whenever a matter is such as to affect people at large, so that they may be legitimately interested in, or concerned at, what is going on; or what may happen to them or others; then it is a matter of public interest on which everyone is entitled to make fair comment. $^{80}$

This can be contrasted with the more passive sense of public interest from the nineteenth century: 'Every subject has a right to comment on the acts of public men which concern him as a subject of the realm, if he do not make his commentary a cloak for malice or slander'. ${ }^{81}$ The earlier case characterises individuals as 'subjects' of the 'realm'; the later decision implicitly acknowledges that a single person can have a range of interest and concerns, and they are not limited to just those that 'concern him' alone (to repeat the nineteenth-century phrase). It is easier, then, to see a role for the news media in the twentieth-century characterisation of public debate than in the preceding one. ${ }^{82}$

Finally, in this overview of the late twentieth century, the spread of personal computers (PCs) was significant ${ }^{83}$ Leaving aside the effect of the internet in the last few years of the millennium (to be discussed in the next section), the growth of access to digital technology gave rise to concepts like 'telework' ${ }^{84}$ It also decentralised, to an extent, the entertainment industry, with the rise of computer games. While these did not, directly, go to the governance of individuals ${ }^{85}$ (though working from home

\footnotetext{
${ }^{73}$ Miller, Governing the Present, 18.

${ }^{74}$ Social Security Contributions and Benefits Act 1992 s. 28(1)(c).

${ }^{75}$ Miller, Governing the Present, 173. Punk, its music and culture, is an example of this. See, generally, Savage, England's Dreaming.

${ }^{76}$ For a discussion of their use, see Organisation for Economic Co-operation and Development, Dispute Settlement Provisions in International Investment Agreements. The authors noted that "even some of the oldest treaties in the sample, dating back to 1960, provide for basic ISDS mechanisms": Organisation for Economic Co-operation and Development, Dispute Settlement Provisions in International Investment Agreements, 10. More generally, in terms of the placing of the State within both the international system and the discipline of economics, the World Trade Organization (WTO) superseded the General Agreement on Tariffs and Trade in 1994 and also covered trade in services and intellectual property.

77 The work of Foucault fits within the broader categories of post-modernism and post-structuralism, both of which can be seen to accord with Lyotard's aphorism of the "incredulity toward metanarratives": Postmodern Condition, xxiv.

${ }^{78}$ Such as the eight-hour day protests of the nineteenth century, or the suffragette protests of the early twentieth century.

${ }^{79}$ For a more nuanced understanding of the analysis of protest movements, see Schock, "Practice and Study of Civil Resistance" and the works therein cited.

${ }^{80}$ London Artists v Littler [1969] 2 QB 375, 391.

${ }^{81}$ Parmiter $v$ Coupland (1840) 6 M \& W 105, 108.

82 Though the news media did not get an effective "public interest" defence until the last year of the twentieth century, in Reynolds $v$ Time Newspapers [1999] UKHL 45.

${ }^{83}$ The use of the term "PC" is not meant to privilege the IBM compatible machines over those of other manufacturers. This discussion is meant to cover all of the devices that allowed computing at home without a dedicated link to a central processing machine.

${ }^{84}$ See, for example, Di Martino, "Telework." Later that decade, research was being published considering telework in terms of "computer networks": see, for example, Wellman, "Computer Networks as Social Networks."

${ }^{85}$ To be clear, the argument is not that the advanced liberalism of the time led to the technology, only that both are conditions of possibility for what we are experiencing now.
} 
did represent an acknowledgement of self-responsibility on the part of the worker) the technology was a significant step on the way to the internet of the twenty-first century.

\section{A Digital Fourth Family of Governmentality?}

Unsurprisingly, then, it is evident that the practices of governance have changed over the past two centuries - these practices are continuing to change. The balance of this article argues that, with the rise of digital technologies (themselves constituent of individuals), we are now in a period that can be characterised as a fourth family of governmentality.

\section{Homo Economicus, Corporations and Digital Technology}

Governmentality is about the constitution of the subject by practices of governance. With respect to the economy, then, a digital fourth family should show at least hints of difference in the make-up of homo economicus. One aspect of this is the rise in the use of cryptocurrencies. As Bitcoin, for example, is not backed by a central bank, ${ }^{86}$ the decision to trust in the currency reflects a different economic constitution of the self than that of someone who only trusts cash or bullion. ${ }^{87}$ Further, anyone with access to the internet and sufficient computing power can mine Bitcoin, and anyone with a mobile phone and the right software can use the currency, thereby shifting the control of currency away from central banks. Finally, while not limited to their economic selves, Bitcoin is commonly used as anonymous payment for goods and services on the Dark Web. ${ }^{88}$ The cryptocurrency, then, facilitates the conduct of illegal activities; that is, it enables individuals to act against 'proper conduct' of society, while remaining 'true' to their internalised practices with respect to their drug use (if that is what they bought) and to their life as a member of a digital community.

There are a number of other effects of the internet, and algorithms, on the behaviour of corporations and their customers in this era of 'surveillance capitalism'. ${ }^{89}$ With respect to corporations, the data they gather can influence their behaviour and may, in turn, be used to attempt to influence the behaviour of consumers. In this sense, the data is 'constitutive' in the way that Foucault sees power as constitutive in governance. ${ }^{90}$ That is, the data contributes to how corporations and, through them, their consumers behave. Corporations use data in two key ways. The first is that it is now a tradeable commodity ${ }^{91}$ though instruments, such as the European Union General Data Protection Regulation, mean that there are some limits to its trading. The second way data is used is to better align the corporations' interests with those of consumers. From the corporations' side, this can be in tailoring their products to match consumer preferences (thereby enhancing profits), or it can be to produce advertising to attempt to change the minds of consumers to be more interested in the goods or services of the corporation-and, of course, data is used to allow for a more focused use of the advertising. ${ }^{92}$

In effect, too, the use and analysis of data is an extension of the classificatory systems in the nineteenth-century registers in law. A range of information about individuals is now placed in a range of databases to be analysed in accordance with the interests of the corporations. Consumers, or at least a significant number of them, know they are being surveilled when they are online. People accept the use of cookies on their browser, and they know that their searches and purchases are tracked, leading to advertisements that are more tailored to their circumstances. ${ }^{93}$ Further, consumers participate in online review processes, sharing their opinions of goods and services for the benefits of others. They may also modify their behaviour through using reviews as inputs into their own purchasing decisions. As such, the data recording and review technologies are now constitutive of these consumers qua consumers. To be clear, it is this interactivity between producer and consumer (including where the interactivity has a firm like Facebook as an intermediary) that sets the digital economy apart from that of even the second half of the twentieth century.

\footnotetext{
${ }^{86}$ As such, it also shows a different relationship with the physical jurisdiction of the State; that is, until the twenty-first century, the territory within which an individual resided could be presumed for most aspects of governance. This is less so in the digital world; however, there is not the space here to discuss this aspect in depth.

87 The use of electronic cards for payment (also facilitated by the digital infrastructure), instead of cash, also reflects a "more modern" economic constitution of the individual than those who prefer cash.

${ }^{88}$ As a relatively mild example: Ćervený, "Cannabis Prices on the Dark Web."

${ }^{89}$ For a discussion of this understanding of capitalism, see Zuboff, "“Big Other' Surveillance Capitalism."

${ }^{90}$ See for example, Foucault, "Subject and Power."

91 This was not the case in the nineteenth century. Confidential information, for example, in the form of trade secrets was only just being accepted by the courts; see, for example, Morison v Moat (1851) 9 Hare 241.

92 The point here is not to applaud the actions of the firms, but to describe them. For a recent analysis of the potential negative effects of the big tech companies in this area, see Amnesty International, Surveillance Giants.

${ }^{93}$ Empirical research even suggests that some users seek to game the system to modify the ads they see: Ruckenstein, "Algorithms, Advertising and the Intimacy of Surveillance."
} 
Data and algorithms are not only used by corporations. Local authorities in the UK, for example, have to undertake data matching to ensure the correct Housing Benefit is paid. ${ }^{94}$ Further, the National Fraud Initiative, in the same country, is a 'data matching exercise conducted by the Cabinet Office to assist in the prevention and detection of fraud'.$^{95}$ Therefore, the welfare system is now based neither on the State simply providing a benefit, nor on a reliance on recipients doing what they should. Information, instead, is being analysed, with an eye on reducing payments, for the 'better' management of public funds.

Finally, reference can be made to the 'gig' economy. The internet is used as the infrastructure, along with algorithms to match data, for bringing suppliers of goods and services together with their potential customers; ${ }^{96}$ notable platforms are Uber, Airbnb and Airtasker. Of particular interest is the fact that both parties in the arrangement can be rated after a given transaction. This means that there is a real-time assessment of the quality of the driving, in the case of ride-sharing apps, and the behaviour of the passenger (in addition to the constant monitoring of the drivers by the platform itself). This facility is said to promote higher standards on both sides. And, of course, the relationship between the provider and the platform presents a challenge to the application of labour law provisions. ${ }^{97}$ Overall, then, the combination of technologies is having a significant effect on the operation of the modern economy.

\section{Individuals and their Digital Identity}

There are also a number of ways in which the internet and algorithms specifically affect the identity and identification of individuals. Obviously, self-expression, including the circulation of photos, videos, music and prose, is facilitated by the World Wide Web. ${ }^{98}$ Platforms, such as Facebook, YouTube and Instagram, no longer need to be described or defined. The minutiae of a user's day can be recorded, as can their efforts at creativity. There is no guarantee of an audience; however, there are a number of users who have found international fame just from their posts. ${ }^{99}$ Therefore, the network facilitates self-expression to a mass audience as has never been possible before; and, of course, the online search algorithms assist in people finding those with similar forms of self-expression ${ }^{100}$ as themselves, thereby increasing their potential audience.

Search algorithms are avoided by some, as are other forms of surveillance. Online anonymity is sought by a number of individuals through the use of virtual private networks and software that limits traceability, ${ }^{101}$ with reasons being political, social or criminal, such as those who use the Dark Web. The use of cryptocurrency also enables anonymous exchanges. This desire to act without an identity is another form of self-expression. It is not, simply, an expression of a desire for privacy; instead, it is better seen as an active attempt to avoid surveillance or to circumvent the requirements of another entity. ${ }^{102}$

Finally, algorithms are also used by the State, or potentially corporations, ${ }^{103}$ to identify and target individuals. ${ }^{104}$ The most obvious example of this is facial recognition technology. Images of individuals taken in public locations (or scraped from the internet) can be compared, using algorithms, to images in databases. Multiple interactions with the technology would allow the system to track an individual's travel and, consequently, predict where the person may be going-therefore, this technology

\footnotetext{
94 "Every authority granting housing benefit - (a) shall take such steps as appear to them appropriate for the purpose of securing that persons who may be entitled to housing benefit from the authority become aware that they may be entitled to it": Social Security Contributions and Benefits Act 1992 s. 123(3).

${ }_{95}$ Cabinet Office, National Fraud Initiative Report, 4. The Initiative is authorised by the Local Audit and Accountability Act 2014 , Part 6.

${ }^{96}$ There is also the new job of "influencer" in which some individuals engage with the goods and services of suppliers. Other consumers, then, may modify their behaviour based on the influencer's assessment of the product. There is not the room to discuss this further here.

${ }^{97}$ For a discussion of some of the legal ramifications of the gig economy, see McGaughey, "Uber, the Taylor Review, Mutuality"; and Minter, "Negotiating Labour Standards."

${ }^{98}$ It also allows the recording of the same for posterity. There remains a poem, of the current author, online, 20 years after it was accepted for publication (it is not clear how many times the page has been accessed).

${ }^{99}$ PewDiePie, for example, has over 100 million subscribers to his YouTube channel. There are, of course, others who have substantial followings online, but based on more traditional routes to fame; for example, Cristiano Ronaldo, a professional footballer, has over 160 million Instagram followers, and Arianna Grande, a pop singer, has over 150 million followers.

${ }^{100}$ Including political self-expression - therefore, the internet, enabling the connection of people, separated by distance, with similar political views.

${ }^{101}$ Including the Tor search engine.

102 That is, VPNs can be used to avoid jurisdictional limits on access (e.g., Netflix and the availability of different content in different countries) and can be used to access restricted material (e.g., pornography).

${ }^{103}$ Uber has, for example, announced that it would use this technology as a means of monitoring those who drive for them, at least in London. Uber has had its licence to operate in that jurisdiction withdrawn on the basis, in part, that unauthorised drivers were operating on their platform: Topham, "Uber Loses London Licence."

${ }^{104}$ Another example is the (lack of) monitoring of international funds transfers by Westpac (see, e.g., "Westpac Bank 'Breached AntiMoney Laundering Laws"'); noting, of course, that it was monitoring by the Australian Transaction Reports and Analysis Centre that gave rise to the allegations.
} 
enables us to be controlled by our identity. This, at one level, merely builds on the use of photographs on passports and drivers' licences (though originally neither included photos); more broadly, however, the technology allows an ongoing practice of monitoring of individuals, rather than just the occasional surveillance when the person interacts with an agent of the State.

\section{Fake News as Digital Political Expression}

'Fake news' is a useful exemplar for the (partially) digitally constituted individuals of this century. It sits at the nexus of knowledge, identity and the internet and is seen as being contrary to a desire for 'true news'. ${ }^{105}$ Fake news, here, is understood to cover 'news articles that are intentionally and verifiably false, and could mislead readers'. ${ }^{106}$ It can be differentiated, at least in theory, from political propaganda and commercial 'spin', ${ }^{107}$ if only on the basis that any specific claims in fake news can be assessed in terms of falsifiability. A key aspect of fake news is that, for misinformation to be effective, ${ }^{108}$ there needs to be a knowledge of, if not a connection with, the intended audience for the work.

Given the political nature of the communications, one audience is those who are of a like mind to the creator, the second audience is those who are of a different political persuasion to the creator and the third is the wider community. With respect to the first group, it is suggested that a key function of fake news is to bind together those with a similar political viewpoint; ${ }^{109}$ that is, those who have been constituted by the same political practices. In these cases, fake news is not aimed at changing the minds of the opposition or even of those undecided voters, ${ }^{110}$ but is simply an expression of the political views of its creator. The use of social media algorithms to propagate fake news allows the consumer's own preferences and connections to guide which stories they read. ${ }^{111}$ Therefore, here, misinformation may be aimed at maintaining a particular self-image and a place within a specific (online) political community.

Politically speaking, the interests of the 'competition', the second audience, are significantly different to those of the creator of fake news. ${ }^{112}$ Not only are they interested in promoting different candidates, they are also interested in furthering different policy objectives, as they are constituted by different practices. The effect of fake news on this audience depends, in part, on an assessment of how tied members of this audience is to their views and an assessment of how gullible they are (such that they would give credence to the fake news stories). ${ }^{113}$ Both of these audiences, of course, are linked to the constitution of self in that political leanings are a key part of the sense of self of many individuals - though, given the range of practices that all individuals are exposed to, very few are totally constituted by a given ideology. ${ }^{114}$

When it comes to the wider society as the audience, there is value in considering the mouthpiece for society: the news media. The media has a particular role given that they claim a place in terms of labelling pieces of expression as fake news. ${ }^{115}$ However, the media is not an impartial observer; ${ }^{116}$ the mainstream media is a collection of corporate entities that have a role in generating and brokering knowledge. ${ }^{117}$ The individuals who make decisions in the companies have internalised practices around both the

\footnotetext{
105 The importance of truth in the public sphere is often justified in terms of the role of knowledge in public debate and in the democratic process. That said, elections are not held in environments of perfect information, and "spin" and half-truths are commonplace While there is no longer a requirement that election advertisements are true, there is a requirement that publications produced during an election are not misleading or deceptive: Commonwealth Electoral Act 1918 s. 329. For the decision around Boris Johnson’s claim regarding the $£ 350$ million given to the European Union every week, see Johnson v Westminster Magistrates' Court [2019] EWHC 1709.

${ }^{106}$ Allcott, "Social Media and Fake News," 213.

${ }^{107}$ A range of publications fall under the umbrella of "fake news," including "fabricated content," "manipulated content," "imposter content," "misleading content," "false context or connection" and "satire and parody": Digital Culture, Media and Sport Committee, Disinformation and "Fake News," 7.

108 That said, one study suggests that the mere novelty of a fake story is a key reason for it to spread: Vosoughi, "Spread of True and False News Online."

${ }^{109}$ See, for example, Guess, "Selective Exposure to Misinformation."

${ }^{110}$ Either undecided with respect to candidate or, in non-Australian jurisdictions, undecided with respect to the act of voting.

111 The algorithms that support platforms such as Facebook and Google operate as "filters" that "limit the amount of attitude-challenging information a user sees": Parliamentary Office of Science and Technology, Online Information and Fake News, 2.

${ }^{112}$ For a study of the political tribalisation of the internet, see Narayanan, "Polarization, Partisanship and Junk News Consumption."

${ }^{113}$ Research using simulations also suggests that it depends on how many individuals in the network are actively trying to deceive others: see, for example, Kopp, "Information-Theoretic Models of Deception."

${ }^{114}$ This has been discussed in terms of the "incompleteness" of modernity: Malpas, "Governance and Failure." It can also be considered in terms of the relative number of practices that attach to a given "node" of practices: Dent, "Not All Practices Are Equal."

${ }^{115}$ An editorial in the New York Times, for example, referred to fake news as a "digital virus": "Facebook and the Digital Virus."

${ }^{116}$ Further, even within the mainstream media, there are different owners with their own political viewpoints. Fox News in the US is a common example of a news channel with a particular viewpoint. More generally, see Gerber, "Does the Media Matter?"

${ }^{117}$ For a discussion of concerns around the accuracy of the news in the nineteenth century, see Samuel, "To Fix Fake News."
} 
need for the corporation to turn a profit, ${ }^{118}$ and around the value of 'true' information for the effective conduct of democracy and society. However, such beliefs are still contingent and contestable.

One of the challenges for the media relates to the potential for fake news to take consumers away from the companies' own websites. That is, if consumers feel that they get sufficient information from the social media feeds, then there is less need for them to source it from the more commercial outlets. To reinforce this, one study found that fake news was more effective, in social media at least, than were more traditional news stories. ${ }^{119}$ Fake news is also a threat to the news media because it can call into question the veracity of every publication that claims to be news; therefore, this challenges the integrity of the news media as a source of information - and any challenge to the media's integrity is a challenge to its bottom line.

The importance of fake news in the political process raises a particular issue, unique to the United States (US), with respect to the capacity to regulate misinformation. It is well known that the First Amendment to the US Constitution allows a greater freedom of speech in that country. The Sullivan rules ${ }^{120}$ mean that, for public figures, the plaintiff has to show that the publisher of the defamatory content acted with 'actual malice'. To succeed, it must be proven that the publisher actually knew the material was false, or at least that the publisher had a 'high degree of awareness' of the publication's 'probable falsity' and recklessly disregarded that danger. ${ }^{121}$ As such, in the absence of fraud (as in the deliberate telling of lies), those subject to fake news stories in the US may not be able to seek redress under the libel law for any damage they have suffered; their internalised desire to protect their self-image, then, prompts calls for the regulation of fake news.

\section{A Digital Fourth Family of Governmentality}

It appears that a society that includes the extensive use of digital networks, and algorithms, is a society that is governed under what can be seen to be a new family of governmentality. That is, the new technologies have facilitated changed relationships between the individual and the entities that govern them. Revisiting the references to welfare under the first three families, it may be noted that Philip Alston, the United Nations Special Rapporteur on Extreme Poverty and Human Rights, has described the current circumstances as the "emergence of the "digital welfare state". ${ }^{122}$ However, the focus in this section is three-fold: the understanding of the individual in this period, the understanding of 'democracy' and the role for law in this brave new world.

Individuals, now, are constituted to be more active in terms of their governance (or, there is less passivity on their part with respect to their regulation). ${ }^{123}$ Not only does the internet allow us to be more expressive, the gig economy also allows us additional opportunities to earn money. This is not to say that the gig economy is the ideal form of economic organisation. The capacity for the exploitation of workers, as independent contractors rather than employees, is significant; however, it does offer opportunities that were not available before. The engagement with the ratings system also enables individuals to have a say in the governance of others, and the 'complaints' system facilitates individual-to-individual regulation of behaviour. ${ }^{124}$ Finally, the basic notion of privacy may also be shifting with our greater online presence. Privacy has been historically contingent. Its limits have changed and can continue to change. ${ }^{125}$ The argument, here, is not that privacy is no longer relevant; instead, it is that the twentieth-century limits of the construct may not be fully applicable now. ${ }^{126}$

\footnotetext{
${ }^{118}$ Notably, since the end of the stamp tax in the nineteenth century, the news media is relatively unconstrained by the law, other than the limits placed by laws that affect everyone, such as those of libel.

${ }^{119}$ Silverman, "This Analysis Shows How Viral Fake Election News."

${ }^{120}$ After New York Times $v$ Sullivan 376 US 254 (1964).

${ }^{121}$ St Amant $v$ Thompson 300 US 727, 731 (1968).

${ }^{122}$ Alston, Report of the Special Rapporteur on Extreme Poverty and Human Rights. A key concern for Alston is the rise in the use of technology, in the form of cashless welfare cards, to control the expenditure of those who need government support. As a related example, the Australian government rolled out an app for social security recipients-for a theoretical analysis of the app, see Sleep, "Visiocracy of the Social Security Mobile App."

${ }^{123}$ See, further, Dent, "Regulating Interactive "Creativity for the Bad.",

${ }^{124} \mathrm{See}$, for example, the efforts of an anonymous individual, known as Omis, to shut down the Instagram accounts of porn actors, even where the latter's accounts do not contravene the platform's terms of use: Fabbri, "Why is Instagram Deleting the Accounts?"

125 The rights listed under the Universal Declaration of Human Rights are linked to the second family of governmentality; the formal protection of privacy (beyond criminal offences with respect to bodily or territorial integrity) did not exist prior to the first family. Notably, one of the first cases around privacy in the UK was Prince Albert v Strange (1849) 2 De G \& S 652; in the US, the seminal privacy article, Warren "Right to Privacy," was not published until the end of the century.

${ }^{126}$ Allowing technology, and the corporations behind it, into one's private space (e.g., Apple's Siri or Google Home) suggests a different boundary to the "private" than would have been accepted a century ago.
} 
In terms of the relationship between individuals and the State, recourse can be had to the notion of 'democracy'; however, this concept is fluid. ${ }^{127}$ The democracy in Australia is not the same as that in the UK or the US, ${ }^{128}$ if only for compulsory voting. The democracy in the US is different to that of the UK, if only because the former is, substantially, a two-party system and the latter has a greater number of parties that achieve representation in the national Parliament. As such, democracy may be seen as a constrained, historically contingent expression of identity. This suggests that any change to the democratic process, because of the use of algorithms and the internet, will lead to a different form of democracy, rather than its removal.

One likely change is the reduction in the power of the mainstream media. ${ }^{129}$ They may no longer be the primary conduit for political news nor political advertising, although with the shift in 'knowledge', they may become a paid, authorised, fact checker for others who contribute political speech. ${ }^{130}$ Finally, further linking democracy to identity, the current model of democracy (voting once every few years) assumes a unitary individual, with relatively consistent interests and preferences. ${ }^{131}$ The more active constitution of individuals renders this model problematic - with the multiple 'selves' of digital natives. ${ }^{132}$ Of course, the recourse to more frequent, online votes (using algorithms for security) would enable a more effective matching of preferences and issues, with the added benefit of a potentially reduced influence of fake news (given the reduced focus on specific election campaigns).

To wrap up this analysis, recourse must be made to law. Traditionally, law has been understood in terms of the relationship between the individual and the State; now, it is more about the relationships between individuals and corporations, or simply between individuals, including the pursuit of libel actions for perceived offence. ${ }^{133}$ Many of those relationships are regulated and constituted by contracts. The terms of service, for example, of platforms, either for expression (Facebook) or work (Uber), constrain what the individual - and to a lesser extent what the company - can do. ${ }^{134}$ There is, of course, a role for the State in the adjudication of those contracts; ${ }^{135}$ though that would be a lesser role than the establishment of clear rules to control society. There also may be a role for the State to set minimum standards for the contracts; however, in the race to be the forum of choice for dispute resolution, there could be a 'race to the bottom' for the most corporation-friendly jurisdiction. Regardless, the decision of an individual to choose to be regulated by contracts, ${ }^{136}$ in an increasingly wide range of activities, reinforces the understanding that we are now experiencing a different form of governance than was evident even 20 years ago.

\section{Conclusion}

Despite the shifts between families of governmentality, the ensemble — and inertia ${ }^{137}$ —of governmentalist practices in the West means that any change in one or two practices will not have a substantial influence on how individuals, and through them the State, are constituted. Practices of governance in other jurisdictions are different, such as the relatively recent shifts in Eastern bloc countries, with those differences affecting the regulation of individuals and other entities. By way of an example, Putin may be seen to remain in power as a result of the tight control of information; conversely, Trump gained the presidency, in part, through the maximising of information flows.

One final conclusion to be drawn is that there are no grounds for asserting that what we had at the turn of the millennium, either in terms of the media or the law, is the best form of governance to be had. Practices of governance have changed for

\footnotetext{
${ }^{127}$ Notwithstanding the claims that democracy itself is under threat; see, for example, Vaidhyanathan, "Digital Democracy."

${ }^{128}$ Expressed differently, "democracy" is a slogan rather than a specific set of practices.

${ }^{129}$ They, as profit-seeking corporations, are, of course, pushing back against the decline in revenue and influence. Noting, too, that the loss in power of the print media, because of the rise in the broadcast media over the course of the twentieth century, would not have been welcomed by the newspaper barons of the nineteenth century. Or, as was suggested in the media — albeit online — the "biggest obstacle to having an informed electorate isn't fake news, but the profit-hungry media seeking clicks and eyeballs": Mudde, "Why the Hysteria."

${ }^{130}$ Some media outlets already do fact-check claims - for example, https://www.abc.net.au/news/factcheck/.

${ }^{131}$ For a discussion of the "extended self" that includes references to the "co-construction of the self" and the "proliferation of multiple online personas." see Belk, "Extended Self in a Digital World," 487-490.

${ }^{132}$ Expressed differently, democracy can be seen in terms of a freedom to express views, rather than the irregular opportunity to cast a formal vote.

${ }^{133}$ As a result, there is less of a role for the State in governance and, consequently, less of a role for the State in the control of practices such as fake news.

${ }^{134}$ For an examination of how contracts themselves can be regulatory, see Dent, "(Potential) Regulatory Function of Contractual Clauses." ${ }^{135}$ Subject to the issues around access to courts that arise from the expense involved, although the gig economy is also influencing the legal profession: see, for example, Thornton, "Towards the Uberisation of Legal Practice."

136 This is not to say the choice is unconstrained. If someone wishes to use Facebook or Twitter, then they have to accept the terms of service. This does not prevent it being a valid contract (for an examination of the issue with respect to software licences, see Buono, "Maximising the Enforceability of Click-Wrap Agreements"). And, sticking with the Foucauldian framework, all choice is constrainedsome just have the appearance of greater freedom than others.

${ }^{137}$ For a discussion of the role of inertia with respect to the change of discursive practices, see Dent, "Not All Practices Are Equal."
} 
centuries, and they will continue to change. What is seen as problematic in 2020 may be accepted as standard practice by 2050 , in the same way that online banking would have been seen as risky 30 years ago. That is not to say that changes should not be questioned; instead, their greater context should be part of the discussion. While this analysis of fake news may not be as negative as others, its implications may be worse. Assuming that the same trends continue, then the practices of governance in the late twenty-first century may be unrecognisable — and even more confronting — to those born into even the fourth family of governmentality.

\section{Bibliography}

\section{Primary Legal Material}

Australia

Australian Citizenship Act 2007 (Cth)

Births, Deaths and Marriages Registration Act 1998 (WA)

Commonwealth Electoral Act 1918

Corporations Act 2001 (Cth)

Crimes Act 1900 (NSW)

Crimes (Criminal Organisations Control) Act 2012 (NSW)

Crimes (High Risk Offenders) Act 2006 (NSW)

Criminal Code 1913 (WA)

Summary Offences Act 1988 (NSW)

Wills Act 1970 (WA)

United Kingdom

An Act of the better regulating and preserving Parish and other Registers of Births, Baptisms, Marriages and Burials in England 52. Geo III, c. 146 (1812)

Births and Death Registration Act, 6 \& 7 Will. IV, c. 86 (1836)

Census Act 1800

Davison v Duncan (1857) $7 \mathrm{El} \& \mathrm{Bl} 229$

Donoghue v Stevenson [1932] AC 562

Friendly Societies Act 1875

E. Hulton $v$ Jones [1910] AC 20

Johnson v Westminster Magistrates' Court [2019] EWHC 1709

Joint Stock Companies Act 1844

Limited Liability Act 1855

Local Audit and Accountability Act 2014

London Artists v Littler [1969] 2 QB 375

Medical Act 1858

Merchant Shipping Act 1854

Merchant Shipping Act 1894

Ministry of Health Act 1919

Morison v Moat (1851) 9 Hare 241

Motor Car Act 1903

National Assistance Act 1948

National Insurance Act 1911

Nordenfelt $v$ Maxim-Nordenfelt [1894] AC 535

Parmiter v Coupland (1840) 6 M \& W 105

Pharmacy Act 1852

Poor Law Amendment Act 1834

Prince Albert v Strange (1849) 2 De G \& S 652

Printing and Numerical Registering Company v Sampson (1875) LR 19 Eq 462

Representation of the People (Equal Franchise) Act 1928

Reynolds $v$ Time Newspapers [1999] UKHL 45

Road Traffic Act 1934

Slanderous Reports Act 1275, 3 Edw 1, c 34

Social Security Contributions and Benefits Act 1992

Toogood v Spyring (1834) 1 C M \& R 181 
United States

New York Times $v$ Sullivan 376 US 254 (1964)

St Amant v Thompson 300 US 727, 731 (1968)

\section{Secondary Sources}

Allcott, Hunt and Matthew Gentzkow. "Social Media and Fake News in the 2016 Election." Journal of Economic Perspectives 31, no 2 (2017): 211-236.

Alston, Philip. Report of the Special Rapporteur on Extreme Poverty and Human Rights. 2019. https://srpovertyorg.files.wordpress.com/2019/10/a 74 48037_advanceuneditedversion-1.pdf.

Amnesty International. Surveillance Giants: How the Business Model of Google and Facebook Threatens Human Rights. 2019. https://www.amnesty.org/download/Documents/POL3014042019ENGLISH.PDF

Barron, Anne. "Foucault and Law." In Introduction to Jurisprudence and Legal Theory: Commentary and Materials, edited by James Penner, David Schiff and Richard Nobles, 955-1034. Oxford: Oxford University Press, 2005.

Belk, Russell. "Extended Self in a Digital World." Journal of Consumer Research 40, no 3 (2013): 477-500. https://psycnet.apa.org/doi/10.1086/671052

Black, Julia. "Critical Reflections on Regulation.” Australian Journal of Legal Philosophy 27 (2002): 1-35.

Bové, Paul. "The End of Humanism: Michel Foucault and the Power of Disciplines." Humanities in Society 3, no 1 (1980): 23-40.

Briggs, Asa. The History of Broadcasting in the United Kingdom. London: Oxford University Press, 1961.

Buono, Francis and Jonathan Friedman. "Maximising the Enforceability of Click-Wrap Agreements." Journal of Technology Law and Policy 4, no 3 (1999): 245-250.

Cabinet Office. National Fraud Initiative Report. 2018. https://assets.publishing.service.gov.uk/government/uploads/system/uploads/attachment_data/file/738283/National-FraudInitiative-Report-2018.pdf

Ćervený Jakub and Jan van Ours. "Cannabis Prices on the Dark Web.” European Economic Review 120 (2019) 1-11. https://doi.org/10.1016/j.euroecorev.2019.103306.

Chapman, Richard. Civil Service Commission 1855-1991: A Bureau Biography. London: Routledge, 2004.

Conboy, Martin. The Press and Popular Culture. London: Sage, 2002.

Cross, Rupert and J. W. Harris. Precedent in English Law. 2nd ed. Oxford: Clarendon, 1991.

Dent, Chris. "The Privileged Few and the Classification of Henwood v Harrison: Foucault, Comment and Qualified Privilege." Griffith Law Review 14, no 1 (2005): 34-60.

Dent, Chris. "Not All Practices Are Equal: An Exploration of Discourses, Governmentality and Scale Free Networks." Social Semiotics 19, no 3 (2009): 345-361. https://doi.org/10.1080/10350330903072698

Dent, Chris. "(Potential) Regulatory Function of Contractual Clauses: Restraints of Trade and Confidential Information in Employment Contracts.” Australian Journal of Labour Law 26, no 1 (2013): 1-19.

Dent, Chris. “"The 'Reasonable Man', His Nineteenth-Century Siblings and Their Legacy.” Journal of Law and Society 44 no 3 (2017): 406-432.

Dent, Chris. "The Locus of Defamation Law Since the Constitution of Oxford." Monash University Law Review 44, no 3 (2018): 491-519.

Dent, Chris. "Regulating Interactive 'Creativity for the Bad': Camgirls, Videogames and Fake News." Interactive Entertainment Law Review 2, no 1 (2019): 3-22. https://doi.org/10.4337/ielr.2019.01.01

Dent, Chris. "The Introduction of Duty into English Law and the Development of the Legal Subject." Oxford Journal of Legal Studies 40, no 1:158-182. doi.org/10.1093/ojls/gqz032

Digital Culture, Media and Sport Committee. Disinformation and 'Fake News. 'Interim Report HC363. House of Commons: London. 2018. https://publications.parliament.uk/pa/cm201719/cmselect/cmcumeds/363/363.pdf

Di Martino, Vittoria and Linda Wirth. "Telework: A New Way of Working and Living." International Labour Review 129, no 5 (1990): 529-554.

Dreyfus, Hubert and Paul Rabinow. Michel Foucault: Beyond Structuralism and Hermeneutics. 2nd ed. Chicago: University of Chicago Press, 1983.

Ewald, Francois. "Justice, Equality, Judgment: On 'Social Justice." In Juridification of Social Spheres, edited by Gunther Teubner, 91-110. Berlin: Walter de Gruyter, 1987.

Ewald, Francois. "Norms, Discipline, and the Law." Representations 30 (1990): 138-161.

Fabbri, Thomas. "Why is Instagram Deleting the Accounts of Hundreds of Porn Stars?". 24 November 2019. https://www.bbc.com/news/blogs-trending-50222380 
"Facebook and the Digital Virus Called Fake News." Opinion. The New York Times. 19 November, 2016. https://www.nytimes.com/2016/11/20/opinion/sunday/facebook-and-the-digital-virus-called-fake-news.html

Foucault, Michel. "Two Lectures.” In Power/Knowledge: Selected Interviews and Other Writings 1972-1977, edited by Colin Gordon, 78-108. New York: Pantheon, 1980.

Foucault, Michel. "Afterword-the Subject and Power." In Michel Foucault: Beyond Structuralism and Hermeneutics, 2nd ed., edited by Hubert Dreyfus and Paul Rabinow, 208-226. Chicago: University of Chicago Press, 1983.

Foucault, Michel. "On the Genealogy of Ethics: An Overview of Work in Progress.” In Michel Foucault: Beyond Structuralism and Hermeneutics, 2nd ed., edited by Hubert Dreyfus and Paul Rabinow, 229-252. Chicago: University of Chicago Press, 1983.

Foucault, Michel. The History of Sexuality Volume 1. London: Penguin, 1990.

Foucault, Michel. "Questions of Method.” In The Foucault Effect-Studies in Governmentality, edited by Graham Burchell, Colin Gordon and Peter Miller, 73-86. London: Harvester Wheatsheaf, 1991.

Foucault, Michel. "Governmentality." In The Foucault Effect-Studies in Governmentality, edited by Graham Burchell, Colin Gordon and Peter Miller, 87-114. London: Harvester Wheatsheaf, 1991.

Foucault, Michel. Archaeology of Knowledge. London: Routledge, 1994.

Foucault, Michel. "The Ethics of the Concern for Self as a Practice of Freedom." In Michel Foucault: Ethics-the Essential Works Vol. 1, edited by Paul Rabinow, 284-301. New York: New Press, 1997.

Foucault, Michel. "On the Government of the Living”. In Michel Foucault: Ethics-the Essential Works Vol. 1, edited by Paul Rabinow, 81-85. New York: New Press, 1997.

Foucault, Michel. "The Subject and Power." In Michel Foucault: Power—the Essential Works Vol. 3, edited by James Faubion, 326-348. London: Allen Lane, 2000.

Foucault, Michel. The Order of Things. London: Routledge, 2002.

Foucault, Michel. The Birth of Biopolitics: Lectures at the Collège de France 1978-1979. Basingstoke: Palgrave Macmillan, 2008.

Gerber, Alan, Dean Karlan and Daniel Bergan. "Does the Media Matter? A Field Experiment Measuring the Effect of Newspapers on Voting Behaviour and Political Opinions." American Economic Journal: Applied Economics 1 no 2 (2009) 35-52.

Guess, Andrew, Brendan Nyhan and Jason Reifler. "Selective Exposure to Misinformation: Evidence for the Consumption of Fake News During the 2016 US Presidential Election Campaign.” Working Paper. http://www.dartmouth.edu/ nyhan/fake-news-2016.pdf

Holt, J. C. Magna Carta, 3rd ed. Cambridge: Cambridge University Press, 2015.

Hunt, Alan. "Foucault's Expulsion of Law: Toward a Retrieval." Law \& Social Inquiry 17 no 1 (1992): 1-38. https://doi.org/10.1111/j.1747-4469.1992.tb00927.x

Hunt, Alan and Gary Wickham. Foucault and Law-Towards a Sociology of Law as Governance. London: Pluto, 1994.

Huzel, J. P. "The Demographic Impact of the Old Poor Law: More Reflections on Malthus." In Malthus and His Time, edited by Michael Turner, 40-59. Basingstoke: Macmillan, 1986.

Kopp, Carlo, Kevin Korb and Bruce Mills. "Information-Theoretic Models of Deception: Modelling Cooperation and Diffusion in Populations Exposed to 'Fake News." PLoS One 13 no 11 (2018). https://doi.org/10.1371/journal.pone.0207383.

Lavenex, Sandra and Frank Schimmelfennig, "EU Rules beyond EU Borders: Theorizing External Governance in European Politics." Journal of European Public Policy 16, no 6 (2009): 791-812. https://doi.org/10.1080/13501760903087696

Leiboff, Marett and Mark Thomas. Legal Theories: Contexts and Practices, 2nd ed. Sydney: LawBook, 2014.

Lobban, Michael. "Corporate Identity and Limited Liability in France and England 1825-67." Anglo-American Law Review 25, no 4 (1996): 397-440.

Lyotard, Jean-Francois. The Postmodern Condition: A Report on Knowledge. Minneapolis: University of Minnesota Press, 1984.

MacLeod, Christine. Heroes of Invention: Technology, Liberalism and British Identity 1750-1914. Cambridge: Cambridge University Press, 2007.

Malpas, Jeff and Gary Wickham, "Governance and Failure: On the Limits of Sociology." Australian and New Zealand Journal of Sociology 31, no 3 (1995): 37-50. https://doi.org/10.1177\%2F144078339503100304

McConvill, James and Martin Joy. "The Interaction of Directors' Duties and Sustainable Development in Australia: Setting Off on the Uncharted Road." Melbourne University Law Review 27, no 1 (2003): 116-138.

McGaughey, Ewan. "Uber, the Taylor Review, Mutuality, and the Duty to Not Misrepresent Employment Status." Industrial Law Journal 48, no 2 (2019): 180-198.

Miller, Peter and Nikolas Rose. Governing the Present: Administering Economic, Social and Personal Life. Cambridge, Polity, 2008.

Minter, Kate. "Negotiating Labour Standards in the Gig Economy: Airtasker and Unions New South Wales." Economic and Labour Relations Review 28, no 3 (2017): 438-454. https://doi.org/10.1177\%2F1035304617724305 
Mitchell, Paul. The Making of the Modern Law of Defamation. Oxford: Hart, 2005.

Mudde, Cas. "Why the Hysteria around the 'Fake News Epidemic' Is a Distraction." The Guardian. 7 February, 2018. https://www.theguardian.com/commentisfree/2018/feb/07/hysteria-fake-news-epidemic-distraction

Narayanan, Vidya, Vlad Barash, John Kelly, Bence Kollanyi, Lisa-Maria Neudert and Philip Howard. "Polarization, Partisanship and Junk News Consumption over Social Media in the US." Computational Propaganda Research Project Data Memo 2018.1, 2018. http://blogs.oii.ox.ac.uk/comprop/wp-content/uploads/sites/93/2018/02/PolarizationPartisanship-JunkNews.pdf

Organisation for Economic Co-operation and Development. "Dispute Settlement Provisions in International Investment Agreements: A Large Sample Survey.” Working Paper 2012/02. Organisation for Economic Co-operation and Development, Paris, February 2012. http://www.oecd.org/investment/internationalinvestmentagreements/50291678.pdf

Parliamentary Office of Science and Technology, Online Information and Fake News. POSTNote 559. July 2017. https://researchbriefings.files.parliament.uk/documents/POST-PN-0559/POST-PN-0559.pdf

Popiel, Pawel. "The Tech Lobby: Tracing the Contours of New Media Elite Lobbying Power." Communication, Culture \& Critique 11, no 4 (2018): 566-585.

Popper, Karl. The Logic of Scientific Discovery. London: Hutchinson, 1959.

Rabinow, Paul and Nikolas Rose. "Foucault Today." In The Essential Foucault: Selections for the Essential Works of Foucault, 1954-1984, edited by Paul Rabinow and Nikolas Rose. New York: New Press, 2003.

Reuter, Paul. Introduction to the Law of Treaties. London: Pinter, 1989.

Rose, Nikolas. Powers of Freedom: Reframing Political Thought. Cambridge: Cambridge University Press, 1999.

Ruckenstein, Minna and Julia Granroth. "Algorithms, Advertising and the Intimacy of Surveillance." Journal of Cultural Economy 13 no 1 (2019): 12-24. https://doi.org/10.1080/17530350.2019.1574866.

Russell, Bertrand. Freedom and Organisation 1814-1914. London: George Allen \& Unwin, 1934.

Samuel, Alexandra. "To Fix Fake News, Look to Yellow Journalism.” JSTOR Daily. 29 November, 2016. https://daily.jstor.org/to-fix-fake-news-look-to-yellow-journalism

Savage, Jon. England's Dreaming: Sex Pistols and Punk Rock. London: Faber \& Faber, 1991.

Schock, Kurt. "The Practice and Study of Civil Resistance.” Journal of Peace Research 50, no 3 (2013): $277-290$. https://doi.org/10.1177\%2F0022343313476530

Seaman, Lewis. Victorian England: Aspects of English and Imperial History 1837-1901. London: Methuen, 1973.

Sedgewick, Robert and Kevin Wayne. Algorithms. 4th ed. Boston: Addision-Wesley, 2016.

Silverman, Craig. "This Analysis Shows How Viral Fake Election News Stories Outperformed Real News on Facebook." Buzzfeed. 17 November 2016. https://www.buzzfeednews.com/article/craigsilverman/viral-fake-election-newsoutperformed-real-news-on-facebook

Sleep, Lyndal and Kieran Tranter. "The Visiocracy of the Social Security Mobile App in Australia." International Journal for the Semiotics of Law 30, no 3 (2017): 495-514. https://doi.org/10.1007/s11196-016-9498-1

Thornton, Margaret. “Towards the Uberisation of Legal Practice.” Law, Technology and Humans 1 (2019): 46-63. https://doi.org/10.5204/lthj.v1i1.1277

Topham, Gwyn. "Uber Loses London Licence after TfL Finds Drivers Faked Identity.” The Guardian. 25 November, 2019. https://www.theguardian.com/technology/2019/nov/25/uber-loses-licence-london-tfl

Vaidhyanathan, Siva. "Digital Democracy Will Face Its Greatest Threat in 2020." The Guardian. 25 November, 2019. https://www.theguardian.com/commentisfree/2019/nov/25/digital-democracy-will-face-its-greatest-test-in-2020

Vinokur, Annie. "Malthusian Ideology and the Crises of the Welfare State." In Malthus and his Time, edited by Michael Turner, 170-186. Basingstoke: Macmillan, 1986.

Vosoughi, Soroush, Deb Roy and Sinan Aral. “The Spread of True and False News Online.” Science 359, no 6380 (2018): 1146-1151.

Walter, Ryan. A Critical History of the Economy: On the Birth of the National and International Economies. London: Routledge, 2011.

Warren, Samuel and Louis Brandeis. "The Right to Privacy.” Harvard Law Review 4, no 5 (1890): $193-220$.

Wellman, Barry, Janet Salaff, Dimitrina Dimitrova, Laura Garton, Milenia Gulia and Caroline Haythornthwaite. "Computer Networks as Social Networks: Collaborative Work, Telework and Virtual Community." Annual Review of Sociology 22 (1996): 213-238.

“Westpac Bank 'Breached Anti-Money Laundering Laws.”” BBC. 20 November 2019. https://www.bbc.com/news/business50483398

Wilkinson, Nick. An Introduction to Behavioural Economics. Basingstoke: Palgrave Macmillan, 2008.

Zuboff, Shoshana. "'Big Other'/Surveillance Capitalism and the Prospects of an Information Civilisation." Journal of Information Technology 30, no 1 (2015): 75-89. 